\title{
The Effect of Country-of-Origin Image, Product Knowledge, Product Involvement toward purchase decisions of Asus Laptops
}

\author{
F.F. Nazarudin ${ }^{1}$, A.A. Amalia ${ }^{2}$, L. Dhikriyah ${ }^{3}$, Y. Wijaya ${ }^{4}$ \\ ${ }^{1} 1$ st Faculty of Economics and Business, Diponegoro University, Indonesia
}

\{fajrulmufc@gmail.com\}

\begin{abstract}
Currently Indonesia has joined the ACFTA, which has an impact on various global products entering the Indonesian market, one of them is laptops Asus from Taiwan. This study aims to analyze the effect of Country-of-origin Image, Product Knowledge, Product Involvement toward purchase decisions of Asus Laptops on Yogyakarta. In this study the sample obtained as many as 130 respondents selected by using purposive sampling method with data collection techniques using questionnaires. The analysis tool used is Multiple Regression and use validity test, reliability test, $t$ test, $F$ test, and determination using SPSS 25.0 application The result of this research are as follow: (1) All independent variable simultaneously have significant effect on purchase decision of Asus Laptops (2) Product knowledge has a positive and significant effect on purchase decision of Asus Laptops. (3) Product involvement has a positive and significant effect on purchase decision of Asus Laptops. All hypotheses are accepted except the first hypothesis which states that country-of-origin image affects purchase decisions.
\end{abstract}

Keywords: Purchase Decision, Country-of-origin Image, Product Knowledge, Product Involvement.

\section{Introduction}

Recent years, competition between companies is getting tougher so that companies, whether old or new, need to innovate in order to be able to compete and survive. This is due to the significant increase in consumer demand for products that meet their satisfaction. This condition has driven companies to keep coming up with something new and different from the rest to generate enough interest from consumers for their products and increase consumers' inclination to buy their products. There are numerous factors that underlie consumers' consideration in purchasing a product. The image of the origin country is one of the factors, and it is one of the key factors in marketing related to consumer decisions (Lin and Chen, 2006). Since it was first researched by Schooler (1965), 'the county-of-origin image' has influenced consumer's acceptance, behavior, and intention to buy. The country-of-origin image is usually attached to a certain specific product, as shown in a study by Nagashima,[1][2][3] which stated that the Japanese people perceive Germany as a country that manufactures luxury cars, the United Kingdom as the best textile producer, and France as the 
best cosmetics manufacturer. Furthermore, Sumarwan also stated that Indonesian consumers are known for preferring imported products as they are perceived to have a higher quality in comparison to local products, and even more so when these products originated from developed countries, in which the product's country of origin becomes a major consideration for consumers.[4] Shirin and Kambiz found that when a certain country carries a certain positive image to the consumers, they would have a higher perception of quality and overall evaluation of the products produced in that country and will further influence their purchasing decisions. [5] Therefore, it can be said that products that are produced in countries with a positive image are perceived to have a higher quality than products that are produced in countries with a negative image. If a consumer has a certain level of affection towards a specific country to the extent that it develops positive perceptions, then it would surely influence the consumer to buy products produced in that country.

Aside from the country of origin factor, consumer knowledge of a certain product is also one of the key factors in purchasing decisions.[1] Consumers generally would buy a product if they have enough information about the product. The knowledge of this information derives from the consumer's experience with the product, the information shared by other people, or from commercials the consumer previously watched. Hawkins and Mothersbaugh said that product knowledge can be obtained from a number of trusted sources such as friends or people closest to us.[6] However, although they can be trusted, they are not necessarily the experts. Furthermore, Hawkins and Mothersbaugh explained that, as an alternative, sales agents and advertisers may have sufficient knowledge and may be trusted, however, consumers are generally skeptical of them.[6]

Another factor that influences purchasing decisions, aside from the image of country of origin and product knowledge, is product involvement.[1] According to Kotler and Armstrong, consumers generally consider a certain product to have a high involvement if that product is expensive, risky, rarely bought, and considerably expressive.[7] A purchase with low involvement occurs when a product is cheap and frequently purchased.[8] Hence, it can be said that when a consumer perceives a product to be valuable, then the consumer will become highly involved and tend to seek more information about the product, therefore increasing the intention to purchase, which then influences consumer behavior.

At the moment, Indonesia is a member of the ACFTA or more fully called ASEAN-China Free Trade Agreement. The effect of Indonesia's membership can be measured by the number of global products that have started to infiltrate Indonesian markets. One of the products that have done so is the portable computer or laptop. Laptops have now become an integral part of many people's daily lives, from children, teenagers, to adults. Laptops are multifunctional, meaning they can be utilized for various purposes such as studying, completing assignments, completing office work, designing, watching films, listening to music, playing games, and many more. Hence, laptops are now considered as a vital part of our lives. The increasing need for laptops is the driving factor behind the rise in demand, therefore increasing the competitiveness among laptop-selling businesses. There are a wide variety of laptop brands available in the market, such as Macbook, Asus, Acer, Lenovo, Dell, HP, Samsung, and others. All of these brands compete with each other by offering a wide array of features or by offering competitive prices. One of the most popular laptop brands in Indonesia currently is Asus. Asus is one of the brands that originated from Taiwan (P.R. China). Taiwan is a sovereign nation, albeit still considered as a part of China by the U.N. Chinese products can easily integrate within the Indonesian society. One of the key factors behind that is the cheap, affordable price that suits people with middle to low income. However, it needs to be said that although most people prefer Chinese products due to their cheap prices, the quality of their 
products is still below Japanese products or products from other countries. [9] Nevertheless, Asus is still considered as a reliable brand, proven by the number of accolades Asus received in the recent Computex 2017, such as the Best Choice Golden Award, the Best Choice of the Year Award, and the Computex D\&I (Design and Innovation) Award.

Currently, Indonesian consumers generally have a preference for Asus laptops. In 2017, Asus laptops dominated the Indonesian market share with 40,7\%, the highest among other brands (www.idc.co.id, 2017). Asus laptops also received a considerably high rating, with the brand cemented the second place in the top 10 laptops ranking, as rated by laptomag in 2017.

\section{Literature Review}

\subsection{Country-of-Origin Image}

Kotler and Keller state that the country-of-origin image is the associations and mental beliefs of a person in a product that is generate by the country-of-origin of the product.[10] Keegan and Green suggest that one of the facts in global marketing today is that perceptions and attitudes towards a particular country often apply to products and brands that are known from these countries, so if a person have a good perception of a country, then most likely they will also consider the products from that country to be good, and vice versa, if a person perception of a country is bad, then they will also consider the products from that country to be bad which in turn will affect purchase decisions.[11]

\subsection{Product Knowledge}

Peter and Olson explain that each consumer has different levels of knowledge which will later be used to interpret new information and make purchase decisions.[12] Sumarwan state that product knowledge is a collection of information about products including prices, brands, product categories, product terminology, attributes or features, and preconseption about products.[4] Another explanation is given by Bruks, 1985 in Shirin and Kambiz, which states that product knowledge came from the memory or knowledge obtained by consumers, the more consumers know about a product, the consumers tend to consider making a purchase.[5]

\subsection{Product Involvement}

Kotler and Keller (2016) define product involvement based on the level of interaction and activity that consumers do in response by marketing stimuli. Furthermore, Peter and Olson explain that involvement is a condition that affect consumers and direct their cognitive and affective processes and their behavior when making decisions.[12] Perceptions of consumer perceptions of the importance and relevance of an object, event, or activity. The consumer is involved with the product and has a personal relationship with the product, if he or she perceives that a product has personal relevance.[12] High involvement is a high level of consumer attention to a product, whereas low involvement is a low level of consumer attention to a product.[1] Furthermore, Kotler and Armstrong also say that consumers will be more involved in purchasing if the product is expensive, risky, rarely purchased, and expressive.[8] 


\subsection{Purchase Decision}

In general, purchase decisions are related to the decision to buy which brand is more suitable for consumers.[8] Kotler and Armstrong states that purchase decisions are one of the step in the decision making process where consumers buy a product.[8] Decision making according to Kotler and Keller is an activity in which individuals are directly involved in obtaining and using the goods offered.[10] Decision-making process starts with processing information and evaluation by consumers in choosing a product, and the last stage is product selection by consumers. Product information collected by consumers is usually related to the brand, country-of-origin, price, quality of the product.

\subsection{Research Hypotheses}

\section{a) Effect of Country-of-origin Image on Purchase Decision}

Research conducted by Javed and Hasnu concluded that there is significance influence between country-of-origin image to purchase decisions. Nagashima argues that consumers are willing to purchase a product associated with country-of-origin image such as cultural, political, historical, and economic.[13] Product information based on the country which the product is made is an important factor in the purchase decisions. Consumer will have a higher view or perception and evaluation of the products if the country have a positive image, and it will increase purchase intention which will affect purchases. So, if a consumer likes a certain country, it will be a factor in making purchase decisions. Based on the previous explanation, proposed hypothesis 1 as follows: H1. Country-of-Origin image has a positive and significant effect on purchase decisions

\section{b) Effect of Product Knowledge on Purchase decisions}

Research conducted by Lin and Chen concluded that purchase decisions affected significantly by knowledge.[1] Brucks, revealed that product knowledge is determined based on the memory or knowledge of consumers, the more consumers know about a product they will buy, the more likely consumers will consider making a purchase.[5] Consumers will look for more information about the product they are going to buy, so that consumers will have knowledge about the product which will later influence purchase decisions.[1] Based on the previous explanation, proposed hypothesis 2 as follows: H2. Product knowledge has a positive and significant effect on purchase decisions

\section{c) Effect of Product Involvement on Purchase decisions}

Research conducted by Shirin and Kambiz stated that product involvement have singnificant influence on purchase decisions.[5] Goldsmith and Emmert, revealed that product interactions play an important role in consumer behavior, if the level of interaction increases, consumers will seek further product information which will further foster purchase intentions and ultimately influence purchase decisions.[1] Based on the previous description, proposed hypothesis 3 as follows: H3. Product involvement has a positive and significant effect on purchase decisions 


\subsection{Theoretical Model}

The research model used in this study aims to determine the effect of country-of-origin image, product knowledge, and product interaction on purchasing decisions. The research model in this study is depicted in Figure 1.

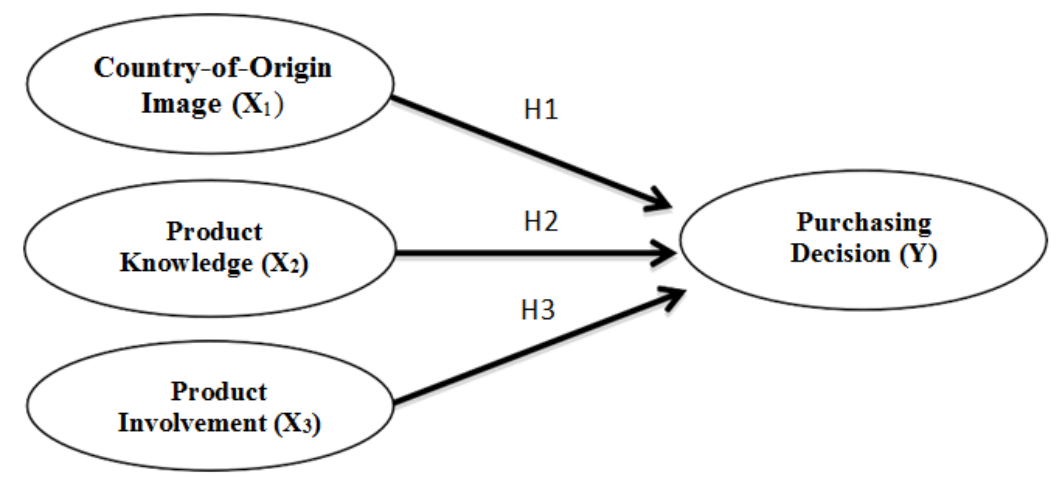

Fig. 1. Research Model

Source : Shirin \& Kambiz (2011), Javed \& Hasnu (2013)

\section{Methodology}

This study included in the kind of quantitative research by processing the results of research into statistical analysis, and this research is a type of causality research which discribe the influence relationship between the independent variables. Populiation in this study are 130 people who use Asus laptops in Yogyakarta and sample technique used is purposive sampling by determining a sample of people who have bought (involved in purchasing decisions) and are currently using Asus laptops in Yogyakarta and are at least 17 years old. The data collection method used a questionnaire with a Likert scale of 1-5. The analytical approach apply in this research uses multiple regression analysis. Multiple regression analysis is used to confirm the relationship between one dependent and independent variable (Hair et al., 2010), testing of this research instrument uses Pearson Correlation as validity with valid criteria if the significance value (Pearson Correlation) $<0.05$ according to Sekaran (2006) and Cronbach's Alpha Reliability as reliability with reliable criteria if the Cronbach's Alpha value $>$ 0.6 according to Sekaran (2006). The normality test was used in this study to determine whether the distribution of the data was normal or not as measured by the KS test with normal criteria if the KS value was $>0.05$ (Hair at al, 2010). The $t$ test is used in this study to test the hypothesis by partially knowing the connection between independent variable and dependent variable. The $\mathrm{F}$ test is also used in this study to test the feasibility of the model. (Ghozali, 2006).

\section{Results and Discussions}

After distributing 130 questionnaires, there were 9 questionnaires that were invalid or not in accordance with the specified respondent criteria. So that of the 130 questionnaires 
distributed, 121 questionnaires could be processed. The results of the characteristics of the respondents were obtained with the percentage of male as much as $54.5 \%$ and $45.5 \%$ female, the age of the respondents who dominate is $21-23$ years as much as $43.8 \%$, the occupation is dominated by college students as much as $59.5 \%$, SMA / SMK with $71.1 \%$ dominating the last education category, and the most places to live in DIY are from Bantul with 31.4\%.

\subsection{Validity and Reliability Test Results}

Validity and reliability tests were carried out by distributing questionnaires to 40 respondents and processed using SPSS 25 which can be seen in Table 1.

Table 1. Validity and Reliability Test Result

\begin{tabular}{|c|c|c|c|}
\hline \multirow[t]{2}{*}{ Variable } & \multirow[t]{2}{*}{ Question Items } & Validity & Reliability \\
\hline & & Pearson Correlation & Cronbach's Alpha \\
\hline \multirow{8}{*}{$\begin{array}{l}\text { Country-of-origin } \\
\text { Image }\end{array}$} & Taiwan has high economic growth & 0,000 & \multirow{8}{*}{0.766} \\
\hline & Taiwan is highly industrialized & 0,000 & \\
\hline & Taiwan has a high standard of living & 0,000 & \\
\hline & Taiwan has workers with & 0,000 & \\
\hline & high skill & & \\
\hline & Taiwan's product quality is good & 0,000 & \\
\hline & Taiwan products to be proud of & 0,000 & \\
\hline & Taiwan products are reliable & 0,000 & \\
\hline \multirow{7}{*}{$\begin{array}{c}\text { Product } \\
\text { knowledge }\end{array}$} & Knowing Asus laptops well & 0,000 & \multirow{7}{*}{0.807} \\
\hline & Has a lot of information about & 0,000 & \\
\hline & Asus laptop & & \\
\hline & Interested in finding additional information & 0,000 & \\
\hline & $\begin{array}{l}\text { Can differentiate between Asus laptops and } \\
\text { other laptops }\end{array}$ & 0,000 & \\
\hline & Know about the whole laptop & 0,000 & \\
\hline & Asus & & \\
\hline \multirow{6}{*}{$\begin{array}{c}\text { Product } \\
\text { Involvement }\end{array}$} & Asus laptops are desirable products & 0,000 & \multirow{6}{*}{0.811} \\
\hline & Asus laptops are essential & 0,000 & \\
\hline & Asus laptops are worth using & 0,000 & \\
\hline & The Asus laptop is a product it is & 0,000 & \\
\hline & Needed & & \\
\hline & Asus laptops will be cared for and looked after & 0,000 & \\
\hline \multirow{5}{*}{ Buying decision } & Buying an Asus laptop because of the confusion & 0,000 & \multirow{5}{*}{0.806} \\
\hline & Sure to buy an Asus laptop & 0,000 & \\
\hline & $\begin{array}{l}\text { Choose to buy an Asus laptop than } \\
\text { another laptop }\end{array}$ & 0,000 & \\
\hline & Decided to buy an Asus laptop & 0,000 & \\
\hline & Great buying an Asus laptop & 0,000 & \\
\hline
\end{tabular}

Table 2. Normality Test Results

\begin{tabular}{ccc}
\multicolumn{3}{c}{ Table 2. Normality Test Results } \\
\hline $\mathbf{N}$ & Mean & $\mathbf{1 2 1}$ \\
\hline \multirow{3}{*}{ Normal Parameters } & Std. & 3,260 \\
& Deviation & \\
\hline \multirow{3}{*}{ Most Extreme Differences } & Absolute & 0.072 \\
& Positive & 0.060 \\
& Negative & -0.072 \\
\hline Statistical Test & 0.072 \\
\hline Asymp. Sig. (2-tailed) & 0.196 \\
\hline
\end{tabular}


Table 3. Results of Multiple Regression Analysis

\begin{tabular}{|c|c|c|c|c|c|c|c|}
\hline \multirow[t]{2}{*}{ Model } & \multirow{2}{*}{$\begin{array}{c}\text { Standardized } \\
\text { Coefficients } \\
\text { Beta } \\
\end{array}$} & \multicolumn{2}{|c|}{ t Test } & \multicolumn{2}{|c|}{ F Test } & \multicolumn{2}{|c|}{$\begin{array}{c}\text { Coefficients } \\
\text { Determination (R2) }\end{array}$} \\
\hline & & $\mathbf{t}$ & Sig. & $\mathbf{F}$ & Sig. & $\mathbf{R 2}$ & Adjusted R2 \\
\hline (Constant) & & 1,281 & 0.203 & & & & \\
\hline Country-of-Origin & 0.141 & 1,819 & 0.071 & & & & \\
\hline Image (CNA) & & & & 22,757 & 0,000 & 0.368 & 0.352 \\
\hline $\begin{array}{l}\text { Product Knowledge } \\
\text { (PP) }\end{array}$ & 0.336 & 3,409 & 0.001 & & & & \\
\hline $\begin{array}{l}\text { Products } \\
\text { Involvement } \\
\text { (KP) }\end{array}$ & 0.271 & 2,840 & 0.005 & & & & \\
\hline \multicolumn{8}{|c|}{ Dependent Variable: KB (Purchase Decision) } \\
\hline $\begin{array}{l}\text { Independent Variable: } \mathrm{C} \\
\text { (Product Engagement) }\end{array}$ & NA (Country-o & f-origin & Imag & PP & duct & Know & ge), KP \\
\hline
\end{tabular}

Table 1, it can see that the question items of all variables have a significance value smaller than alpha or 0.05 so that all question items are declared valid. Furthermore, based on Table 1, all variables have a Cronbach's Alpha value greater than 0.6 so that the instrument is declared reliable.

\subsection{Normality Test Results}

Before testing the hypothesis, a normality to find out whether the data distribution is normal or not and processed using SPSS 25. Table 2, the Asymp value Sig. equal to 0.196 which means greater than the significance level of 0.05 . So it can be said that the distribution of data from these instruments is normally distributed.

\subsection{Multiple Regression Analysis}

Multiple regression analysis in this research was processed using the SPSS version 25.0. The issue of the multiple regression analysis can be found at Table 3. Based on Table 3 above, the regression equation is obtained as follows:

$$
\mathrm{Y}=0.141 \mathrm{X} 1+0.336 \mathrm{X} 2+0.271 \mathrm{X} 3
$$

\subsection{T test}

Table 3 discribe the results of the $t$ test are as follows:

\section{a) The influence of the image of the country-of-origin on purchasing decisions}

The results of the $t$ in Table 3 states that the variable of the country-of-origin image (X1) has a beta coefficient value of 0.141 and a significance value of 0.071 which means greater than the alpha value $(0.05)$. This means hypothesis 1 , namely the image of the country-of- 
origin has a positive and significant effect on the decision to purchase Asus laptops is declared unsupported.

\section{b) The influence of knowledge on purchasing decisions}

The results of the $t$ test in Table 3 state that the prdouk knowledge variable (X2) has a beta coefficient value of 0.336 and a significance value of 0.001 which means it is smaller than the alpha value (0.05). This means that the product knowledge variable has a partially positive and significant influence on purchasing decisions.

\section{c) Effect of product involvement on purchasing decisions}

The $t$ test effect can be seen in Table 3 which states that the product involvement variable (X3) has a beta coefficient value of 0.271 and a significance value of 0.005 , it means smaller than the alpha value $(0.05)$. It means this variable has a partially positive significant influence on purchasing decisions.

\subsection{F test}

Based on Table 3, by looking at the effect of the $\mathrm{F}$ test, it is concluded a significance value of $0.000<0.05$, it is concluded that all independent variables, namely the image of the country-of-origin (X1), product knowledge (X2) and product involvement (X3) that are included in the model have a simultaneous influence on the dependent variable, namely the purchase decision $(\mathrm{Y})$.

\subsection{Determination Coefficient Test}

Table 3, the effect of the determination coefficient test (R2) are obtained by looking at the Adjusted R Square value of 0.352 . This means that variations in the dependent variable in the model, namely purchasing decisions $(\mathrm{Y})$ can be related by independent variables, namely the image of the country-of-origin (X1), product knowledge (X2) and product involment (X3) $35.2 \%$, while the remaining $64.8 \%$ is related by other variables.

\subsection{Discussion}

\section{a) The image of the country-of-origin does no significant effect on purchase decisions}

Based on the hypothesis testing result, prove that the image of the product origin does not significantly affect the decision to purchase Asus laptops in Yogyakarta. So the conclusion is hypothesis 1 is not supported because the relationship between variables is not significant. This research showed that buyers of Asus laptops in Yogyakarta ignore the country-of-origin' image of Asus laptops as a consideration in buying. This study have a different result from the study conducted by Javed and Hasnu (2013), which state that there is a significant positive effect between the image of the product origin country on purchasing decisions using Japanese electronic product objects. However, this study have a consistent result with Tati et al. (2015) state the product origin country is not the first consideration that consumers need to pay attention to, which used Samsung as a different product but still relevant. 
There are many things that consumers need to consider before making a purchase. Usually, consumers prioritize price, brand, quality, or specifications before making a purchase. Besides that, consumers usually tend to recognize and know where their product was made after making a purchase, not before deciding to buy. Based on the confirmation from previous researchers and the description above, hypothesis 1 is not supported. It is stated that the image of the product origin country has no significant effect on purchasing decisions.

\section{b) Product knowledge has a positive and significant effect on purchase decisions}

Based on the hypothesis testing result, show that product knowledge has a positive and significant effect on Asus laptops' purchasing decisions in Yogyakarta. So it can be concluded that hypothesis 2 is supported because between those variables there is a positive and significant relationship. This research showed that most Asus laptop buyers in Yogyakarta have an excellent knowledge of Asus laptops to influence their buying decisions. These results are consistent with Lubis and Magnadi (2015) research, which revealed that there is a significant positive influence between product knowledge on purchasing decisions, which uses Acer notebooks as the research object.

Many things need to be considered by consumers before making a purchase. Consumer knowledge of a product is one of the considerations that consumers need to pay attention to. Brucks, 1985 in Shirin and Kambiz, 2011 revealed that product knowledge is based on the memory or knowledge of consumers. The more consumers know about a product they are going to buy, the more consumers consider making a purchase. Based on the confirmation from previous research and the description above, hypothesis 2 is supported, and it is stated that product knowledge has a positive and significant effect on purchasing decisions.

\section{c) Product involvement has a positive and significant effect on purchase decisions}

Based on the hypothesis testing result, show that product involvement positively and significantly affects purchasing decisions for Asus laptops in Yogyakarta. So the conclusion that hypothesis 3 is supported because of the positive and significant effect of the relationship between those variables. this study have a consistent result with the research by Shirin and Kambiz (2011), state that between product involvement and purchasing decisions there is a significant positive effect, which uses various types of cellphone brands as the research's object.

Many factors influence purchasing decisions; product involvement is one of the factors that can influence it. Goldsmith and Emmert, 1991, in Lin and Chen, 2006 revealed that product involvement plays an important role in consumer behavior. Consumers will seek further product information, which will foster purchase intentions and ultimately influence purchase decisions if the level of involvement increases. Based on the confirmation from previous research and the description above, hypothesis 3 is supported, and it is stated that purchasing decisions are influenced by product involvement in a positive and significant manner.

\section{Conclusions}

a) The image of the product origin country has no significant effect on the decision to purchase Asus laptops in Yogyakarta. Hypothesis 1 is not supported. It had been proven 
that the image of the country-of-origin is not an important consideration for consumers in making purchases.

b) Product knowledge has a positive and significant effect on Asus laptop purchasing decisions in Yogyakarta. Hypothesis 2 is supported. It had been proven that the knowledge of a consumer's product affects his buying decision.

c) Product involvement has a positive and significant effect on Asus laptop purchasing decisions in Yogyakarta. Hypothesis 3 is supported. It had been proven that product involvement has a role in influencing consumers to make purchases.

\subsection{Limitation}

a) The image of the product origin country, product knowledge, and product involvement, cannot describe the effect of purchasing decisions as a whole because measuring purchasing decisions can still be measured by various variables and other aspects.

b) This study only uses one country-of-origin to measure the image of the product origin country, so that it is not able to describe the image of the product origin country from other countries.

\subsection{Suggestion}

a) For the Company, The findings in this study indicated that the image of the product origin country has no significant effect on purchasing decisions, so that it cannot fully influence consumers to buy Asus laptops. So Asus should continue to improve its quality and continue to innovate and carry out promotions or advertisements to cover their shortcomings.

b) For Further Researchers, This study only used three independent variables, namely the image of the product origin country, product knowledge, and product involvement. Other variables can be used to test purchasing decisions. Further research is needed to test other variables or other factors related to purchasing decision behavior, such as product quality, promotion, or innovation. So that it can provide a broader picture of what factors can influence the behavior of purchasing decisions. After that, the next researcher can add or replace objects from different countries to compare other countries' image, whether it can influence purchasing decisions.

\section{References}

[1] Lin L Y and C S C 2006 The influence of the country-of-origin image, product knowledge and product involvement on consumer purchase decisions: An empirical study of insurance and catering services in Taiwan ConsumerMarketing 23(5): 248-65

[2] Schooler R D 1965 Product Bias in Central American Common Market J. Mark. Res. Vol. 2

[3] Nagashima A 1977 A comparative made in product image survey amon Japanese businessmen J. Mark. Vol 41 pp 95-100

[4] Sumarwan U 2015 Perilaku Konsumen (Bogor: Ghalia Indonesia)

[5] Sekaran U 2006 Research Methods For Busines. ed T E of the C-O I Jakarta Shirin, K., and Kambiz, H.H., 2011 (Jakarta: Salemba Empat.)

[6] Al H et 2010 Multivariate Data Analysis. (England) 
[7] Kotler A 2010 Principles Of Marketing. 13 Edition. New Jersey. Upper Saddle River: Pearson Prentice Hall

[8] Kotler, P., dan Armstrong G 2012 Principles Of Marketing (United States: Pearson Education)

[9] Merdeka 2018 uang kenapa-barang-buatan-china-dianggapmurahan https://www.merdeka.com

[10] Kotler, P., dan Keller K L 2016 Marketing Management (England: Pearson)

[11] Keegan, Warren J., and Green M C 2017 Global Marketing, Ninth (England)

[12] Peter, J.Paul dan Olson J C 2013 Perilaku Konsumen \& Strategi Pemasaran (Jakarta: Salemba Empat)

[13] Nagashima A 1970 A Comparison of Japanese and US Attitude Toward Foreign Products J. Mark. Vol 34 pp 68-74 